\title{
Distribution of polychaete feeding guilds in sedimentary environments of the Campeche Bank, Southern Gulf of Mexico
}

\author{
Nayeli Domínguez Castanedo • Pablo Hernández Alcántara • \\ Vivianne Solís-Weiss · Alejandro Granados Barba
}

Received: 10 March 2011/Revised: 16 October 2011/Accepted: 31 October 2011/Published online: 12 November 2011

(C) Springer-Verlag and AWI 2011

\begin{abstract}
The aim of this study was to analyze the trophic structure of the polychaete assemblages found in the Campeche Bank, southern Gulf of Mexico and to examine the effect of the sediment composition on the spatial distribution of the feeding guilds. In all, 2,662 organisms belonging to 160 species and 16 feeding guilds were identified. Filter-feeders (Fabricinuda trilobata and Bispira melanostigma) dominated. Five groups of stations were defined based on feeding guilds: one, in the southwest, characterized by motile jawed burrowers $(17.14 \%$ contribution); the second, from the southeast to the northwest, characterized by seven guilds (45.25\%), mainly filterfeeders and surface deposit-feeders; the third, in the southwest, characterized by three guilds $(42.13 \%)$, mainly discretely motile tentaculate filter-feeders and motile unarmed burrowers; group four, in the east, was characterized by sessile tentaculate filter-feeders $(63.68 \%)$; and group five, in the center and to the north, was characterized
\end{abstract}

Communicated by H.-D. Franke.

N. Domínguez Castanedo

Posgrado en Ciencias del Mar y Limnología,

Universidad Nacional Autónoma de México,

Circuito Exterior S/N, Ciudad Universitaria S/N,

Mexico, Distrito Federal, Mexico

P. Hernández Alcántara · V. Solís-Weiss $(\square)$

Lab. Ecologia y Biodiversidad de Invertebrados Marinos, Instituto de Ciencias del Mar y Limnología, Universidad Nacional Autónoma de México, Circuito Exterior S/N, Ciudad Universitaria S/N, Mexico, Distrito Federal, Mexico

e-mail: solisw@cmarl.unam.mx

A. Granados Barba

Instituto de Ciencias Marinas y Pesquerías,

Universidad Veracruzana, Hidalgo \# 617,

Col. Río Jamapa, Boca del Río, 94290 Veracruz, Mexico by four guilds (53.69\%), mainly discretely motile tentaculate filter-feeders. The variety of feeding guilds was higher in the northwest with seven guilds, and the lowest variety was found in the east and south with only one or two guilds. Contrary to the starting hypothesis, the sediment composition was not the main factor that determined the distribution of the polychaete feeding guilds. Instead, salinity and depth were more important for the spatial arrangement of the trophic groups. The feeding guilds of polychaetes proved to be more sensitive to environmental changes than density or diversity.

Keywords Polychaetes - Feeding guilds - Trophic structure $\cdot$ Benthic communities

\section{Introduction}

The study of feeding guilds is important to understand spatial and temporal changes in benthic communities (Heip 1992; Wieking and Kröncke 2003) and parts of them such as polychaete assemblages (Paiva 1993; Muniz and Pires 1999). Polychaete feeding guilds are based on the relationships between food particle sizes, feeding habits and the motility patterns associated with feeding (Fauchald and Jumars 1979; Pagliosa 2005). A common assumption is that deposit-feeders are abundant in muddy habitats while suspension feeders dominate in sandy habitats (Gray 1981). Nevertheless, besides the frequent co-occurrence of the two groups, some species can modify their trophic habits in response to food availability, and also their ability to colonize bottoms with high sediment mobility, as exemplified by some spionids (Maurer and Leathem 1981). In addition, many species are not invariably associated with a single sediment type, but their trophic organization relates to 
factors such as organic content and granulometric characteristics of sediments (Snelgrove and Butman 1994). Pagliosa (2005) used feeding guilds to develop an ecological and environmental impact assessment in which feeding guilds were related to environmental parameters, disturbance, availability of resources or interspecific competition. Therefore, the pattern is not universal but might be highly dependent on habitat conditions (Pinedo et al. 1997). A fundamental question to analyze the feeding structure is how to separate species into feeding guilds. Fauchald and Jumars (1979) proposed a conceptual pattern to classify polychaete species according to their feeding features. A strong increase in studies on the diets and the biology of polychaetes in the last years has given rise to a major interest in the use of feeding guilds in studies on polychaete communities (Pagliosa 2005). However, the original feeding scheme by Fauchald and Jumars (1979) has remained basically the same and few studies have analyzed the significance of the complete pattern in the study of polychaetes assemblages (Maurer and Leathem 1981; Maurer et al. 1981; Dauer 1984; Gambi and Giangrande 1985; Gaston 1987; Muniz and Pires 1999; Pagliosa 2005). Despite some early criticism of the original feeding classification (Dauer et al. 1981; Dauer 1984), it seems necessary to revive the use of this important tool for the analysis of communities and to emphasize its importance for ecological and environmental benthic studies.

In the Gulf of Mexico, polychaetes represent a key group in terms of abundance and diversity on the continental shelf (Fauchald et al. 2009). In the Campeche Bank, distribution and diversity of polychaetes have been shown to be mainly influenced by the sediment composition, with diversity increasing with sand content (Hernández Arana et al. 2003; Domínguez Castanedo et al. 2007), but studies on their trophic structure are virtually absent. Thus, the aim of this study was to analyze the changes in the species composition and feeding guilds of the polychaete assemblages in the Campeche Bank, with the hypothesis that most of the variation of the spatial distribution of the polychaete feeding guilds would be associated to the changes in sediment composition present in the Campeche Bank. That is, the feeding guilds were expected to respond to the environmental sediment gradient by the increase of the filter-feeders to the east and northeast where sediments show an increasing percentage of sand, while burrowers and surface deposit-feeders were expected to increase toward the west and south with a decreasing percentage of sand. This kind of study is relevant in a region such as the Campeche Bank where natural and anthropogenic impacts are important (Granados Barba 2001; Hernández Arana et al. 2003; Hernández Arana et al. 2005) and the information obtained could provide a useful tool in environmental monitoring of the area.

\section{Methods}

Study area

The Campeche Bank $\left(18^{\circ} 49^{\prime}-21^{\circ} 35^{\prime} \mathrm{N}\right.$ and $\left.91^{\circ} 00^{\prime}-92^{\circ} 10^{\prime} \mathrm{W}\right)$ is located in the southern Gulf of Mexico. During the winter, it is influenced by strong winds from the north, known as "nortes", while in the summer, tropical storms or hurricanes from the southeast and abundant rains are common, together with the resultant river discharges. These phenomena cause seasonal changes in the physico-chemical characteristics of both the water and the sediments (Hernández Arana et al. 2005; Granados Barba et al. 2009). There is a gradual shift from terrigenous (west) to carbonate (east) sediments due to the absence of rivers in the east. A transitional zone with seasonally varying limits is characterized by a mixture of sediments (Yáñez Arancibia and Sánchez Gil 1983; Granados Barba 2001; Domínguez Castanedo et al. 2007). The Campeche Bank shows a large shelf (150 km wide) unaffected by rivers and with carbonate sediments (Fig. 1). The establishment and distribution of the local macrobenthic fauna is influenced by all these factors (Hernández Arana et al. 2003). The diversity of polychaetes is low in the transitional zone, influenced by the Grijalva-Usumacinta river discharge, and it is high in the east of the Campeche Bank. There are also species replacements from the terrigenous to the carbonate sediments, from lumbrinerid species in the terrigenous sediments to spionids in the transitional zone and to sabellids in the carbonate sediments (Domínguez Castanedo et al. 2007).

Sampling and data analysis

The biological material was collected during the "nortes" season (December 2001) on board the R/V "Justo Sierra" in 21 stations distributed in a grid in the inner continental shelf

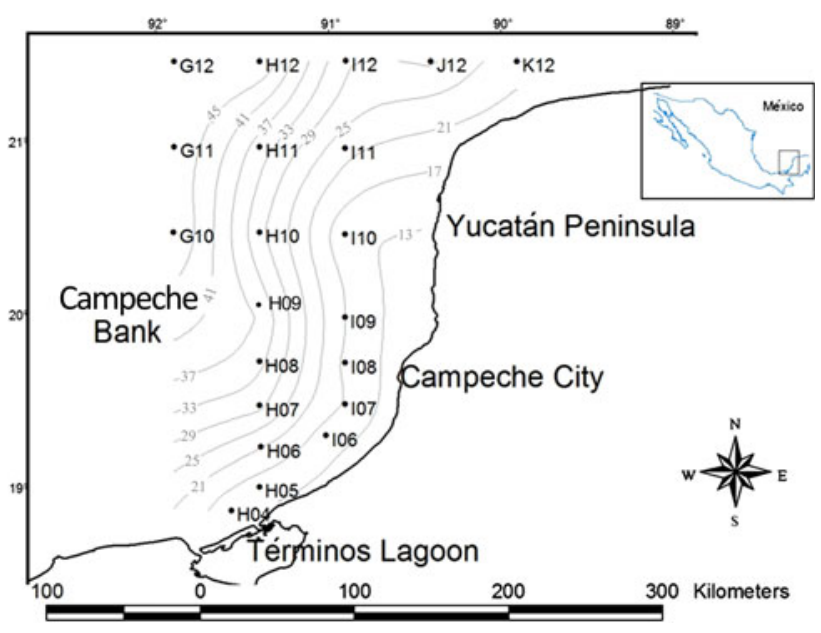

Fig. 1 Study area. Campeche Bank with the sampling stations (isobaths in meters) 
(15-49 m) of the study area (Fig. 1). A Reineck box corer $\left(2.5 \mathrm{~m}^{2}\right)$ was used to sample a uniform area of $0.08 \mathrm{~m}^{2}$ per sample (with no replicates).The sediment was then sieved through a $0.5-\mathrm{mm}$ mesh. The organisms were fixed with $4 \%$ formaldehyde and preserved in $70 \%$ ethanol. The polychaetes were identified to species level and transferred to the National Polychaete Collection in the Instituto de Ciencias del Mar y Limnología, Universidad Nacional Autónoma de México (CPICML-UNAM, DFE.IN.061.0598) (Table 1).

In this study, we followed the classification by Fauchald and Jumars (1979) which is based on a set of relationships between food particle size and composition, the mechanisms involved in food ingestion, and motility patterns associated with the feeding processes. Accordingly, polychaetes can be divided in five or six trophic categories: carnivores (C); surface deposit-feeders (S); burrowers (B); filter-feeders (F); herbivores $(\mathrm{H})$; and omnivores $(\mathrm{O})$. These categories combined with the three types of feeding motility [motile (M); discretely motile (D); and sessile (S)], and the three types of buccal structures used in food encounter and ingestion [jawed (J); tentaculate (T); and "other structures", usually sac-like pharynxes $(\mathrm{X})$ ], produce 22 feeding guilds that are biologically acceptable (Fauchald and Jumars 1979).

The density (ind. $/ 0.08 \mathrm{~m}^{2}$ ) of the polychaetes of each feeding guild was analyzed by multivariate statistical methods of ordination. The differences in density values between stations and feeding guilds were evaluated by a $t$-test of dependent samples. After the fourth root transformation of the data, a similarity matrix was constructed with the 21 stations and also with the 16 feeding guilds using the Bray-Curtis index. An NMDS ordination was used to analyze the relationships among the feeding guilds. The SIMPER analysis was used to determine the species contribution to the groups with the PRIMER v.5 software (Field et al. 1982; Clarke and Gorley 2001). The distribution of the groups of the feeding guilds from the NMDS is shown on a map with the ArcView Gis 3.2 software.

A canonical correspondence analysis (CCA) using the CANOCO program (ter Braak 1988) was also carried out in order to show in a single diagram the direct interpretation of the relationships between species, stations and environmental factors. The relationship between feeding guilds and environmental variables was tested by the Monte-Carlo permutation test (Manly 1990).

\section{Results}

Community structure

In all, 2,662 polychaetes (160 species belonging to 44 families) were collected and classified into 16 feeding guilds (Table 1).
According to spatial variations in density and species composition, the more abundant fauna was found in shallow sandy sediments near the coast (in front of the city of Campeche): stations I09 (209.8 ind./0.08 $\mathrm{m}^{2}$; mean 1.31 ind./spp. $\left.* 0.08 \mathrm{~m}^{2}\right)$, I08 (98.6 ind $/ 0.08 \mathrm{~m}^{2}$; mean 0.616 ind./spp. $\left.* 0.08 \mathrm{~m}^{2}\right)$, and I07 (31.4 ind $/ 0.08 \mathrm{~m}^{2}$; mean 0.196 ind./spp.*0.08 $\mathrm{m}^{2}$ ) (Fig. 2). However, the $t$-test showed that only in station I07, the higher values observed were significantly different from other stations $(t$ value $=1.9849, P=0.0489)$, since in station $\mathrm{I} 09$ the higher density was mainly due to the sabellids Fabricinuda trilobata $\left(90.2\right.$ ind./0.08 $\left.\mathrm{m}^{2}\right)$ and Bispira melanostigma ( 85.6 ind. $/ 0.08 \mathrm{~m}^{2}$ ), and in station I08 the density values were associated only with $B$. melanostigma ( 88 ind. $/ 0.08 \mathrm{~m}^{2}$ ). On the other hand, the densities were significantly lower in shallow transitional (mixed terrigenous and carbonate) sediments from the southernmost stations: H04 (4.75 ind./0.08 $\mathrm{m}^{2} ; t$ value $=2.71$, $P=0.007)$ and $\mathrm{H} 05$ (1.6 ind./0.08 $\mathrm{m}^{2} ; t$ value $=2.02$, $P=0.0451)$.

\section{Ordination analysis}

The NMDS analysis based on feeding guilds (Fig. 3), showed five main groups of stations. The first ( $\mathrm{H} 07$ and H08 stations) was represented by the BMJ feeding guild species (17.1\% average similarity) and was located to the west, in front of the Términos lagoon and subjected to the influence of the Grijalva-Usumacinta river discharges (Fig. 4). This group included the fauna with the lowest densities and number of species, occurring at depths of 30-34 m with a sand content of 1.4-6.2\%.

The second group (stations G10, G11, G12, H09, H10, H11, I06, I07, and I10) was characterized by HMJ, FDT, BMX, FST, SDT, SMT, and HDJ guilds $(45.3 \%$ average similarity), thus displaying the highest variety of feeding guilds, and was located from the southeast toward the north (Fig. 4) in depths of $15-49 \mathrm{~m}$, with an average of $58.5 \%$ in sand content.

The third group (H04, H05, I12, and K12) was characterized by FDT, BMX, and SDT guilds $(42.1 \%$ average similarity); this group was split: one part in the southwest and the other in the northeast (Fig. 4), in shallow depths $(15 \mathrm{~m})$ near the coastline with $6.3-97.1 \%$ of sand.

The fourth group (I08 and I09) was characterized by the FST guild (63.7\% average similarity) and was located to the east of the study area (Fig. 4), in front of the city of Campeche, in shallow sandy bottoms (16.5 m; 95\% sand). The fifth group (H06, H12, I12, and J12) was characterized by FDT, CMJ, BMX, and HMJ guilds $53.7 \%$ average similarity). This group corresponded to the stations found toward north (Fig. 4), in depths of $21-48.7 \mathrm{~m}$ and $26.4-98.9 \%$ of sand. 
Table 1 Species registered in the inner shelf of Campeche Bank with their relative densities and their feeding guilds

\begin{tabular}{|c|c|c|c|c|c|}
\hline & Species & Density (\%) & Trophic group & \multicolumn{2}{|c|}{ Feeding guilds } \\
\hline 1 & Aglaophamus verrilli & 0.43 & Carnivore & CMJ & \\
\hline 2 & Ampharetidae Genus A & 0.04 & Surface deposit feeder & SST & \\
\hline 3 & Amphicteis gunneri & 0.04 & Surface deposit feeder & SST & \\
\hline 4 & Ancistrosyllis sp. A & 0.04 & Carnivore & CMJ & \\
\hline 5 & Aphelochaeta sp. 1 & 0.12 & Surface deposit feeder & SMT & SDT \\
\hline 6 & Aphelochaeta sp. 2 & 0.28 & Surface deposit feeder & SMT & SDT \\
\hline 7 & Aphelochaeta sp. 3 & 0.18 & Surface deposit feeder & SMT & SDT \\
\hline 8 & Aphelochaeta sp. 4 & 0.04 & Surface deposit feeder & SMT & SDT \\
\hline 9 & Aricidea (Acmira) finitima & 0.16 & Herbivore & HMX & SMX \\
\hline 10 & Aricidea (Acmira) philbinae & 0.17 & Herbivore & HMX & SMX \\
\hline 11 & Aricidea (Acmira) sp. 1 & 0.06 & Herbivore & HMX & SMX \\
\hline 12 & Aricidea (Acmira) sp. 2 & 0.96 & Herbivore & HMX & SMX \\
\hline 13 & Aricidea (Acmira) sp. 3 & 0.13 & Herbivore & HMX & SMX \\
\hline 14 & Aricidea (Acmira) taylori & 0.32 & Herbivore & HMX & SMX \\
\hline 15 & Aricidea (Allia) bryani & 0.04 & Herbivore & HMX & SMX \\
\hline 16 & Aricidea (Allia) sp. 1 & 0.02 & Herbivore & HMX & SMX \\
\hline 17 & Armandia maculata & 3.28 & Subsurface deposit feeder & BMX & \\
\hline 18 & Axiothella sp. A & 0.04 & Subsurface deposit feeder & BSX & \\
\hline 19 & Axiothella sp. 1 & 0.04 & Subsurface deposit feeder & BSX & \\
\hline 20 & Bispira melanostigma & 33.25 & Filter feeder & FST & \\
\hline 21 & Capitella sp. & 0.20 & Subsurface deposit feeder & BMX & SMX \\
\hline 22 & Capitellidae Genus 1 & 0.04 & Subsurface deposit feeder & BMX & SMX \\
\hline 23 & Capitellidae Genus 2 & 0.53 & Subsurface deposit feeder & BMX & SMX \\
\hline 24 & Caulleriella cf. zetlandica & 0.08 & Surface deposit feeder & SMT & SDT \\
\hline 25 & Caulleriella sp. 1 & 0.37 & Surface deposit feeder & SMT & SDT \\
\hline 26 & Ceratocephale oculata & 0.19 & Omnivore & HMJ & CMJ, CDJ, SDJ \\
\hline 27 & Ceratonereis irritabilis & 0.05 & Omnivore & HMJ & CMJ, CDJ, SDJ \\
\hline 28 & Ceratonereis versipedata & 0.11 & Omnivore & HMJ & CMJ, CDJ, SDJ \\
\hline 29 & Chaetopterus variopedatus & 0.04 & Filter feeder & FSP & \\
\hline 30 & Chaetozone sp. 1 & 0.03 & Surface deposit feeder & SMT & SDT \\
\hline 31 & Chaetozone sp. 2 & 0.03 & Surface deposit feeder & SMT & SDT \\
\hline 32 & Chone americana & 0.05 & Filter feeder & FST & \\
\hline 33 & Chone duneri & 0.27 & Filter feeder & FST & \\
\hline 34 & Cirrophorus lyra & 0.28 & Herbivore & HMX & SMX \\
\hline 35 & Clymenella sp. & 0.09 & Subsurface deposit feeder & BSX & \\
\hline 36 & Cossura delta & 1.40 & Subsurface deposit feeder & BMX & \\
\hline 37 & Dasybranchus lumbricoides & 0.12 & Subsurface deposit feeder & BMX & SMX \\
\hline 38 & Dasybranchus lunulatus & 0.34 & Subsurface deposit feeder & BMX & SMX \\
\hline 39 & Demonax microphthalmus & 0.05 & Filter feeder & FST & \\
\hline 40 & Diopatra cf. papillata & 0.04 & Omnivore & HDJ & CMJ, CDJ, SDJ \\
\hline 41 & Diopatra cuprea & 0.12 & Omnivore & HDJ & CMJ, CDJ, SDJ \\
\hline 42 & Diopatra neotridens & 0.07 & Omnivore & HDJ & CMJ, CDJ, SDJ \\
\hline 43 & Diopatra tridentata & 0.02 & Omnivore & HDJ & CMJ, CDJ, SDJ \\
\hline 44 & Syllis ferrugina & 0.30 & Carnivore & CMJ & \\
\hline 45 & Eupolymnia nebulosa & 0.05 & Surface deposit feeder & SST & \\
\hline 46 & Eurythoe complanata & 0.04 & Carnivore & CMX & \\
\hline 47 & Exogone dispar & 0.09 & Herbivore & HMJ & CMJ \\
\hline 48 & Exogone lourei & 0.20 & Herbivore & HMJ & CMJ \\
\hline
\end{tabular}


Table 1 continued

\begin{tabular}{|c|c|c|c|c|c|}
\hline \multirow[b]{2}{*}{49} & \multirow{2}{*}{$\begin{array}{l}\text { Species } \\
\text { Paraexogone atlantica }\end{array}$} & \multirow{2}{*}{$\frac{\text { Density (\%) }}{0.30}$} & \multirow{2}{*}{$\begin{array}{l}\text { Trophic group } \\
\text { Herbivore }\end{array}$} & \multicolumn{2}{|c|}{ Feeding guilds } \\
\hline & & & & HMJ & CMJ \\
\hline 50 & Paraexogone caribensis & 0.43 & Herbivore & HMJ & CMJ \\
\hline 51 & Exogone cf. breviantennata & 0.08 & Herbivore & HMJ & CMJ \\
\hline 52 & Fabricinuda trilobata & 23.23 & Filter feeder & FST & SDT \\
\hline 53 & Glycera americana & 0.07 & Carnivore & CDJ & BMJ \\
\hline 54 & Glycera brevicirris & 0.11 & Carnivore & CDJ & BMJ \\
\hline 55 & Glycera papillosa & 0.53 & Carnivore & CDJ & BMJ \\
\hline 56 & Grubeulepis mexicana & 0.21 & Carnivore & CMJ & \\
\hline 57 & Hesionura coineaui & 0.04 & Carnivore & CMS & \\
\hline 58 & Kinbergonuphis cf. cedroensis & 0.42 & Omnivore & HDJ & CMJ, CDJ, SDJ \\
\hline 59 & Kinbergonuphis orenzansi & 0.03 & Omnivore & HDJ & CMJ, CDJ, SDJ \\
\hline 60 & Kinbergonuphis pulchra & 0.45 & Omnivore & HDJ & CMJ, CDJ, SDJ \\
\hline 61 & Kinbergonuphis simoni & 0.37 & Omnivore & HDJ & CMJ, CDJ, SDJ \\
\hline 62 & Kinbergonuphis sp. 1 & 0.04 & Omnivore & HDJ & CMJ, CDJ, SDJ \\
\hline 63 & Kinbergonuphis sp. 2 & 0.14 & Omnivore & HDJ & CMJ, CDJ, SDJ \\
\hline 64 & Laonice cirrata & 0.30 & Filter feeder & FDT & SDT \\
\hline 65 & Leiocapitella sp. B & 0.05 & Subsurface deposit feeder & BMX & SMX \\
\hline 66 & Leiocapitella sp. 1 & 0.08 & Subsurface deposit feeder & BMX & SMX \\
\hline 67 & Leiocapitella sp. 2 & 0.04 & Subsurface deposit feeder & BMX & SMX \\
\hline 68 & Leiocapitella sp. A & 0.25 & Subsurface deposit feeder & BMX & SMX \\
\hline 69 & Leiochrides sp. 1 & 0.04 & Subsurface deposit feeder & BMX & SMX \\
\hline 70 & Lepidasthenia varius & 0.04 & Carnivore & CMJ & CDJ \\
\hline 71 & Levinsenia gracilis & 0.66 & Herbivore & HMX & SMX \\
\hline 72 & Litocorsa antennata & 0.15 & Carnivore & CMJ & \\
\hline 73 & Lumbrinerides aberrans & 0.04 & Omnivore & HMJ & CMJ, CDJ, BMJ \\
\hline 74 & Lumbrinerides sp. 1 & 0.03 & Omnivore & HMJ & CMJ, CDJ, BMJ \\
\hline 75 & Lumbrineris cingulata & 0.04 & Omnivore & HMJ & CMJ, CDJ, BMJ \\
\hline 76 & Lumbrineris latrelli & 0.17 & Omnivore & HMJ & CMJ, CDJ, BMJ \\
\hline 77 & Lumbrineris sp. 1 & 0.04 & Omnivore & HMJ & CMJ, CDJ, BMJ \\
\hline 78 & Lumbrineris sp. 2 & 0.11 & Omnivore & HMJ & CMJ, CDJ, BMJ \\
\hline 79 & Lumbrineris sp. 3 & 0.03 & Omnivore & HMJ & CMJ, CDJ, BMJ \\
\hline 80 & Lysilla sp. A & 0.30 & Surface deposit feeder & SDT & \\
\hline 81 & Magelona pettiboneae & 0.96 & Surface deposit feeder & SDT & \\
\hline 82 & Magelona phyllisae & 0.09 & Surface deposit feeder & SDT & \\
\hline 83 & Magelona polydentata & 0.61 & Surface deposit feeder & SDT & \\
\hline 84 & Magelona sp. B & 0.10 & Surface deposit feeder & SDT & \\
\hline 85 & Magelona sp. G & 0.78 & Surface deposit feeder & SDT & \\
\hline 86 & Magelona sp. L & 0.04 & Surface deposit feeder & SDT & \\
\hline 87 & Malacoceros indicus & 0.26 & Filter feeder & FDT & SDT \\
\hline 88 & Malacoceros sp. 1 & 0.04 & Filter feeder & FDT & SDT \\
\hline 89 & Malmgreniella sp. & 0.04 & Carnivore & $\mathrm{CMJ}$ & CDJ \\
\hline 90 & Mediomastus californiensis & 1.05 & Subsurface deposit feeder & BMX & SMX \\
\hline 91 & Megalomma bioculatum & 0.32 & Filter feeder & FST & \\
\hline 92 & Microspio pigmentata & 0.08 & Filter feeder & FDT & SDT \\
\hline 93 & Monticellina baptisteae & 0.30 & Surface deposit feeder & SMT & SDT \\
\hline 94 & Monticellina dorsobranchialis & 0.24 & Surface deposit feeder & SMT & SDT \\
\hline 95 & Monticellina sp. 1 & 0.04 & Surface deposit feeder & SMT & SDT \\
\hline 96 & Moоreonuphis sp. 1 & 0.08 & Omnivore & HDJ & CMJ, CDJ, SDJ \\
\hline
\end{tabular}


Table 1 continued

\begin{tabular}{|c|c|c|c|c|c|}
\hline \multirow[b]{2}{*}{97} & \multirow{2}{*}{$\begin{array}{l}\text { Species } \\
\text { Mooreonuphis cf. nebulosa }\end{array}$} & \multirow{2}{*}{$\frac{\text { Density (\%) }}{0.04}$} & \multirow{2}{*}{$\begin{array}{l}\text { Trophic group } \\
\text { Omnivore }\end{array}$} & \multicolumn{2}{|c|}{ Feeding guilds } \\
\hline & & & & HDJ & CMJ, CDJ, SDJ \\
\hline 98 & Neanthes micromma & 0.55 & Omnivore & HMJ & CMJ, CDJ, SDJ \\
\hline 99 & Nematonereis hebes & 0.05 & Omnivore & HMJ & CMJ, CDJ \\
\hline 100 & Nephtys incisa & 0.49 & Subsurface deposit feeder & BMJ & \\
\hline 101 & Nephtys squamosa & 0.25 & Subsurface deposit feeder & BMJ & \\
\hline 102 & Ninoë brasilensis & 0.04 & Omnivore & HMJ & $\mathrm{CMJ}, \mathrm{CDJ}, \mathrm{BMJ}$ \\
\hline 103 & Ninoë leptognatha & 0.07 & Omnivore & HMJ & $\mathrm{CMJ}, \mathrm{CDJ}, \mathrm{BMJ}$ \\
\hline 104 & Notomastus americanus & 0.07 & Subsurface deposit feeder & BMX & SMX \\
\hline 105 & Notomastus daueri & 0.04 & Subsurface deposit feeder & BMX & SMX \\
\hline 106 & Notomastus hemipodus & 0.09 & Subsurface deposit feeder & BMX & SMX \\
\hline 107 & Notomastus lineatus & 0.05 & Subsurface deposit feeder & BMX & SMX \\
\hline 108 & Notomastus lobatus & 0.09 & Subsurface deposit feeder & $\mathrm{BMX}$ & SMX \\
\hline 109 & Notomastus tenuis & 0.13 & Subsurface deposit feeder & BMX & SMX \\
\hline 110 & Odontosyllis enopla & 0.04 & Carnivore & CMJ & \\
\hline 111 & Ophiogoniada lyra & 0.04 & Carnivore & CDJ & \\
\hline 112 & Orbinia sp. 1 & 1.86 & Subsurface deposit feeder & $\mathrm{BMX}$ & \\
\hline 113 & Owenia sp. A & 0.34 & Filter feeder & FDT & SDT \\
\hline 114 & Paramphinome jeffreysi & 0.11 & Carnivore & CMX & \\
\hline 115 & Paramphinome sp. B & 0.09 & Carnivore & CMX & \\
\hline 116 & Parapionosyllis uebelakerae & 0.15 & Herbivore & HMJ & CMJ \\
\hline 117 & Paraprionospio yokoyamai & 5.48 & Filter feeder & FDT & SDT \\
\hline 118 & Pectinaria gouldii & 0.05 & Subsurface deposit feeder & BMX & \\
\hline 119 & Phyllodoce (Phyllodoce) arenae & 0.02 & Carnivore & CMS & \\
\hline 120 & Phylo sp. 1 & 0.03 & Subsurface deposit feeder & BMX & \\
\hline 121 & Pionosyllis sp. A & 0.30 & Carnivore & CMJ & \\
\hline 122 & Piromis roberti & 0.04 & Surface deposit feeder & SDT & SMT \\
\hline 123 & Pisione wolfi & 0.04 & Subsurface deposit feeder & BMX & \\
\hline 124 & Poecilochaetus johnsoni & 0.20 & Surface deposit feeder & SDT & \\
\hline 125 & Prinospio (Prionospio) dubia & 0.72 & Filter feeder & FDT & SDT \\
\hline 126 & Prionospio (Apoprionospio) dayi & 0.32 & Filter feeder & FDT & SDT \\
\hline 127 & Prionospio (Minuspio) delta & 0.63 & Filter feeder & FDT & SDT \\
\hline 128 & Prionospio (Minuspio) multibranchiata & 0.11 & Filter feeder & FDT & SDT \\
\hline 129 & Prionospio (Minuspio) perkinsi & 0.08 & Filter feeder & FDT & SDT \\
\hline 130 & Prionospio (Minuspio) sp. 1 & 0.34 & Filter feeder & FDT & SDT \\
\hline 131 & Prionospio (Minuspio) sp. 2 & 0.50 & Filter feeder & FDT & SDT \\
\hline 132 & Prionospio (Minuspio) sp. 3 & 0.24 & Filter feeder & FDT & SDT \\
\hline 133 & Prionospio (Minuspio) cirrifera & 0.13 & Filter feeder & FDT & SDT \\
\hline 134 & Prionospio (Prionospio) sp. 1 & 0.13 & Filter feeder & FDT & SDT \\
\hline 135 & Prionospio (Prionospio) cristata & 1.75 & Filter feeder & FDT & SDT \\
\hline 136 & Protodorvillea kefersteini & 0.14 & Omnivore & HMJ & CMJ, SMJ \\
\hline 137 & Pseudopolydora sp. 1 & 0.04 & Filter feeder & FDT & SDT \\
\hline 138 & Rhynothelepus sp. & 0.15 & Surface deposit feeder & SST & \\
\hline 139 & Rullierinereis mexicana & 0.04 & Omnivore & HMJ & CMJ, CDJ, SDJ \\
\hline 140 & Scolelepis (Parascolelepis) texana & 0.17 & Filter feeder & FDT & SDT \\
\hline 141 & Scolelepis squamata & 0.04 & Filter feeder & FDT & SDT \\
\hline 142 & Scoletoma cf. ernesti & 0.06 & Omnivore & HMJ & CMJ, CDJ, BMJ \\
\hline 143 & Scoletoma sp. 1 & 0.11 & Omnivore & HMJ & CMJ, CDJ, BMJ \\
\hline 144 & Scoletoma sp. 2 & 0.71 & Omnivore & HMJ & CMJ, CDJ, BMJ \\
\hline
\end{tabular}


Table 1 continued

\begin{tabular}{|c|c|c|c|c|c|}
\hline \multirow[b]{2}{*}{145} & \multirow{2}{*}{$\begin{array}{l}\text { Species } \\
\text { Scoletoma sp. } 3\end{array}$} & \multirow{2}{*}{$\begin{array}{l}\text { Density }(\%) \\
0.12\end{array}$} & \multirow{2}{*}{$\begin{array}{l}\text { Trophic group } \\
\text { Omnivore }\end{array}$} & \multicolumn{2}{|c|}{ Feeding guilds } \\
\hline & & & & HMJ & CMJ, CDJ, BMJ \\
\hline 146 & Scoletoma sp. 4 & 0.11 & Omnivore & HMJ & CMJ, CDJ, BMJ \\
\hline 147 & Scoletoma verrilli & 2.06 & Omnivore & HMJ & CMJ, CDJ, BMJ \\
\hline 148 & Scoloplos (Leodamas) rubra & 0.58 & Subsurface deposit feeder & BMX & \\
\hline 149 & Scoloplos (Scoloplos) acmeceps & 0.04 & Subsurface deposit feeder & BMX & \\
\hline 150 & Scoloplos (Scoloplos) texana & 0.04 & Subsurface deposit feeder & BMX & \\
\hline 151 & Sigambra elongata & 0.26 & Carnivore & CMJ & \\
\hline 152 & Sphaerodoropsis vittori & 0.04 & Subsurface deposit feeder & BMX & \\
\hline 153 & Sphaerosyllis sp. & 0.04 & Herbivore & HMJ & CMJ \\
\hline 154 & Spio pettiboneae & 0.08 & Filter feeder & FDT & SDT \\
\hline 155 & Spiophanes bombyx & 0.11 & Filter feeder & FDT & SDT \\
\hline 156 & Sternaspis scutata & 0.04 & Subsurface deposit feeder & $\mathrm{BMX}$ & \\
\hline 157 & Sthenelanella sp. & 0.30 & Carnivore & CMJ & \\
\hline 158 & Syllis ortizi & 0.04 & Carnivore & CMJ & \\
\hline 159 & Terebellides carmenensis & 0.23 & Surface deposit feeder & SST & \\
\hline 160 & Terebellides parvus & 0.13 & Surface deposit feeder & SST & \\
\hline
\end{tabular}

The species named A, B, etc. were identified with the Taxonomic Guide to the polychaetes of the Northern Gulf of Mexico (Uebelacker and Johnson 1984) and they have not been formally named yet, so we kept them as in the guide. The species named 1, 2, etc. are considered potentially new to science and need further revision

Fig. 2 Polychaete densities and species richness in the Campeche Bank

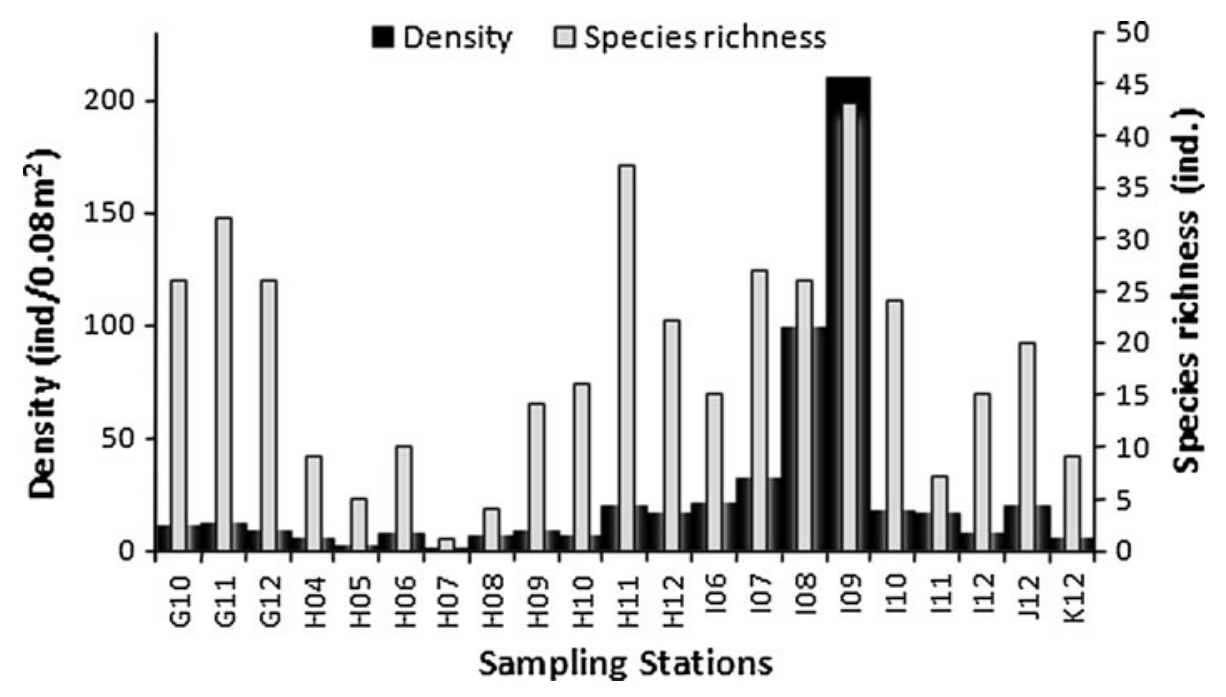

The arrangement of the stations in the NMDS analysis in the study area, showed that no clear distribution pattern emerges that can be attributed to the feeding guilds (Fig. 4). The dominating guild, constituted by the filterfeeders, was the only guild to show a trend. The FST guild (301.7 ind $/ 0.08 \mathrm{~m}^{2}$ ) was more abundant in group 4 , located to the east of the study area; its density decreased to the west as shown in Fig. 3. The FDT guild $\left(62.6\right.$ ind $/ 0.08 \mathrm{~m}^{2}$, present in $85.7 \%$ of the stations) was more abundant in group 5, located to the north, and its density decreased to the east and south of the Bank. So, the sessile and discretely motile filter-feeders decreased toward west and south of the Campeche Bank. In the remaining guilds, lower density values were observed and their distribution was heterogeneous across the Campeche Bank.

The correlation of feeding guilds to environmental data, according to the canonical analysis, was 0.82 for the first axis and 0.74 for the second axis. The Monte-Carlo test was significant $(P=0.04)$ and only the first two axes were analyzed, explaining $78.8 \%$ of the variation of the feeding guilds by the effect of the environmental variables. The spatial variations in the distribution of the feeding guilds were not significantly associated with the sediment composition. A significant correlation was found, however, with 


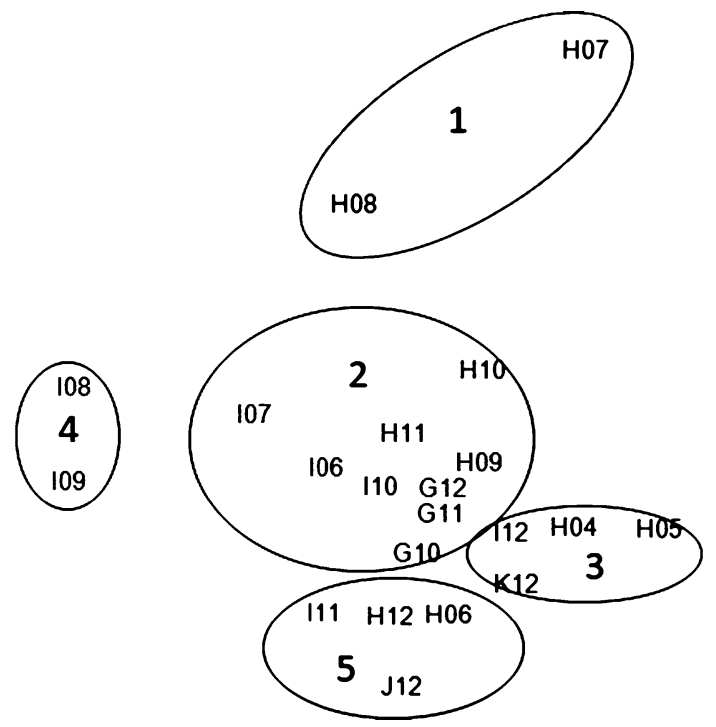

Fig. 3 NMDS analysis of the sampling stations based on the densities of the polychaete feeding guilds (groups numbered 1-5)

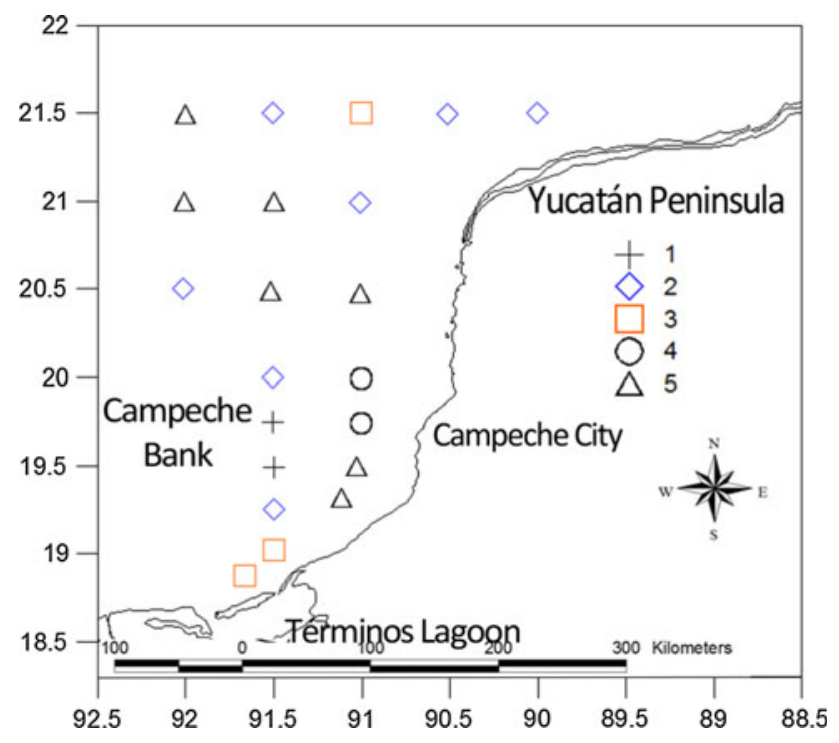

Fig. 4 Distribution of the groups obtained in the NMDS analysis according to their feeding guilds. Group I: BMJ guild; Group 2: HMJ, FDT, BMX, FST, SDT, SMT, and HDJ; Group 3: FDT, BMX, and SDT; Group 4: FST and Group 5: FDT, CMJ, BMX, and HMJ

salinity (0.77) and depth (0.69) in the first axis of the CCA, while $\mathrm{pH}(0.57)$ and sand percentage $(0.38)$ were significant in the second axis. Salinity $(-0.92)$, temperature $(0.73)$, and oxygen $(0.73)$ variations were clearly correlated to depth.

Most of the feeding guilds (CMX, HMJ, HDJ, BMX, BSX, SST, SMT) were distributed in deeper environments with medium values of salinity and sand in the northwest of the study area (Fig. 5). On the other hand, the FST and CDJ guilds were found in shallow stations with high salinity, organic carbon content, and sand content from the northwest to the east, while the CMJ, FDT, and SDT guilds were

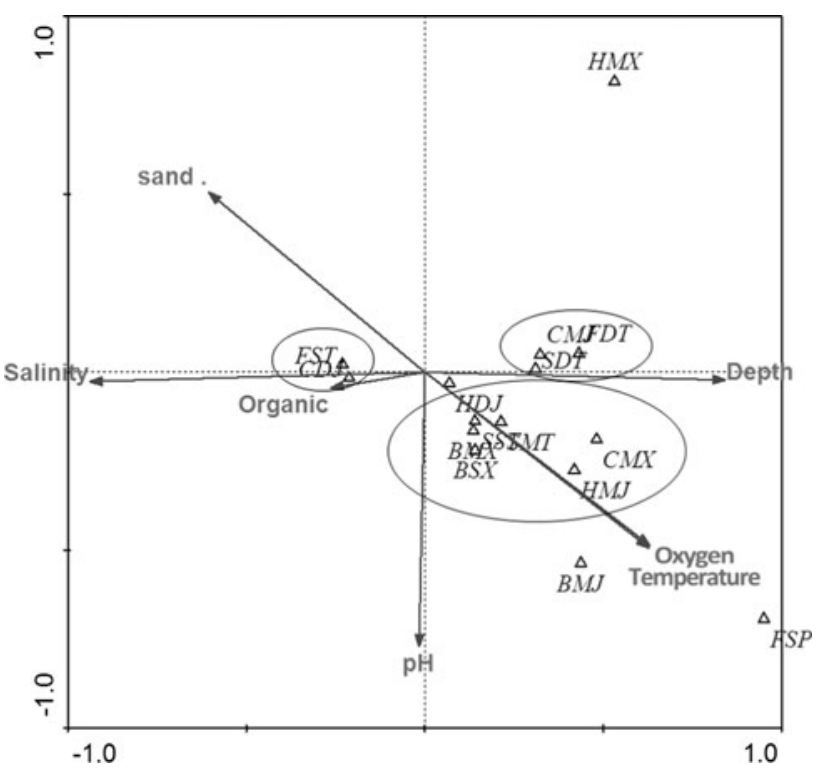

Fig. 5 Canonical correspondence analysis (CCA) ordination diagram showing the feeding guilds and environmental variables relative to axes I and II

located in deeper stations with medium values of salinity and sand from the center to the northwest. The FSP and BMJ guilds were found in deep stations with low salinities, high $\mathrm{pH}$, and muddy bottoms in the west of the Bank. The HMX guild dominated in the deep stations with low salinity and muddy sediments, but contrary to FSP and $\mathrm{BMJ}$, it was distributed in zones with the lowest levels of $\mathrm{pH}$, mainly in the center and north. Then, the filter-feeders showed an ability to tolerate a wider range of changes in environmental conditions, while both the sessile and discretely motile were present only in habitats with at least $7 \%$ sand and clearly dominated in sediments with greater than or equal to $50 \%$ of sand, to the northwest and east of the Bank. The sessile pumping filter-feeders were present only in deep, muddy sediments with high $\mathrm{pH}$ values (station H09). The carnivores also tolerated a wide range of environmental conditions and were located in several regions of the Campeche Bank. The motile jawed carnivores preferred average depths $(25 \mathrm{~m})$, while the motile unarmed preferred deeper stations, both in low salinities and average to low sand content of the sediments. The discretely motile jawed carnivores, on the contrary, preferred the shallow stations with high salinity values. The motile and discretely motile jawed herbivores tolerated average depths, low salinities, low $\mathrm{pH}$ values and low sand percentage. The unarmed motile herbivores tolerated high depths and sand content. On the other hand, the subsurface deposit-feeders do not seem to tolerate significant changes in environmental conditions, and the same probably applies to the burrowers, which occurred only at average depths with low salinities and low sand content in the sediments. 


\section{Discussion}

According to Snelgrove et al. (1997), polychaetes in any benthic community display a wide range of feeding types, although in most soft-bottom communities, suspension (filter-feeders) and deposit-feeders (surface deposit-feeders and burrowers) dominate. In this study the filter-feeders, sessile and discretely motile, tentaculate organisms (FST, FDT) were the most abundant and frequent, although there was also a remarkable contribution of the motile jawed burrowers (BMX) guild. In the Campeche Bank, the highest variety of feeding guilds was found to the northwest where high diversities of polychaetes had already been reported. In contrast, the lowest variety of feeding guilds was found in the southwest of the Campeche Bank where polychaete species diversity is low (Domínguez Castanedo et al. 2007).

Contrary to our expectations, the sediment type was not the main factor influencing the distribution of the feeding guilds in the Campeche Bank. Basically, it was depth that determined the distribution of the feeding guilds even though the range analyzed was only $15-49 \mathrm{~m}$. The variables correlated with depth, mainly salinity and secondarily temperature and oxygen, were also important for the changes in trophic structure. The highest variety of feeding guilds at the deepest stations can be linked to the relative stability of the water-sediment interface found at greater depths (Paiva 1993). As also stated by Fauchald and Jumars (1979), Maurer and Leathem (1981) found that sessile organisms were generally associated with less dynamic and more stable sediments encountered in the deepest environments. Actually, this pattern was also observed in the Campeche Bank, where the FSP and FDT guilds (sabellids and spionids) were very abundant at the deepest stations, located in the middle and outer shelf, which are relatively far from the Grijalva-Usumacinta river discharges. According to Muniz and Pires (1999), the river discharges with their input of terrigenous sediments and suspended particulates obstruct the feeding structures of filter-feeders. Besides, the considerable extension of the continental shelf allows the seasonal upwelling water to remain in the shelf along the euphotic zone for a longer time (Merino 1997), supporting the settling of the filtering species.

High densities of burrowers and surface deposit-feeders were expected to occur close to the Grijalva-Usumacinta discharges in the muddy sediments, but subsurface depositfeeders as well as tentaculate, motile, discrete motile, and motile unarmed burrowers were also very abundant at sandy stations in the center and to the east of the Campeche Bank. In these zones, high values of organic carbon content were registered, although the sediment was coarse, because of the high quantity of organic matter discharged by the Grijalva-Usumacinta river, which is the second major river in the Gulf of Mexico (after the Mississippi river) with a discharge of $4,402 \mathrm{~m}^{3} \mathrm{~s}^{-1}$ (Yáñez Arancibia and Day 2004). This organic matter is transported to the east of the Bank by the main current present during the "nortes" season. The local circulation pattern is from east to west along the coastline and due to the shallow and extended nature of the continental shelf low hydrodynamics prevail in the Campeche Bank (Salas de León et al. 1992) which favor the deposition of the organic carbon in shallower stations in the east. This pattern creates an environment suitable for surface deposit-feeders and burrowers in the eastern sandy stations as also mentioned in other studies (Gambi and Giangrande 1985; Muniz and Pires 1999).

The polychaete feeding guilds represent a fine tool that is more sensitive to detect environmental changes than are density and diversity values, particularly when the guilds are influenced by environmental factors other than sediment type.

The original scheme proposed by Fauchald and Jumars (1979) has remained so far almost unchanged, but adding the omnivore guild to the feeding modes, as suggested by Cheung et al. (2008), may improve the analysis of trophic patterns in the benthic environments. There are some species that can change their feeding mode depending on the availability of resources (Lindsay and Woodin 1995; Hentschel and Larson 2005). In the Campeche Bank, for example, Scoletoma verrilli, one of the most abundant species of the region, has the capacity to exploit different food resources as herbivore, carnivore or motile jawed burrower.

Although the use of polychaete feeding guilds in the analysis of community structures has encountered some objections, we agree with the conclusions of Pagliosa (2005), considering the use of these guilds a suitable tool to analyze polychaete assemblage patterns. Just as the community structure of polychaetes can reflect the condition of the environment, the same applies to feeding guilds, because they are dependent on the environmental variables (Pagliosa 2005) and not only or mainly on sediment type.

Acknowledgments Thanks are due to the late Dr. Felipe Vázquez Gutiérrez (ICML-Universidad Nacional Autónoma de México) head of the "SGM6 PEMEX UNAM" project for the financial support of this study. We also thank M. en C. Ricardo Rojas López for his assistance with the edition of the figures.

\section{References}

Cheung SG, Lam NWY, Wu RSS, Shin PKS (2008) Spatio-temporal changes of marine macrobenthic community in sub-tropical waters upon recovery from eutrophication. II. Life-history traits and feeding guilds of polychaete community. Mar Pollut Bull 56:297-307

Clarke KR, Gorley RN (2001) Primer v 5.0: users manual/ tutorial. Primer-E, Plymouth, p 91 
Dauer DM (1984) The use of polychaete feeding guilds as biological variables. Mar Pollut Bull 15:301-305

Dauer DM, Maybury CA, Ewing RM (1981) Feeding behaviour and general ecology of several spionid polychaetes from the Chesapeake Bay. J Exp Mar Biol Ecol 54:21-38

Domínguez Castanedo N, Rojas López R, Solís Weiss V, Hernández Alcántara P, Granados Barba A (2007) The use of higher taxa to assess the benthic conditions in the southern Gulf of Mexico. Mar Ecol Prog Ser 28:161-168

Fauchald K, Jumars PA (1979) The diet of worms: a study of polychaete feeding guilds. Oceanogr Mar Biol Annu Rev 17:193-284

Fauchald K, Granados Barba A, Solís-Weiss V (2009) Polychaeta (Annelida) of the Gulf of Mexico. In: Felder DL, Camp DK (eds) Gulf of Mexico origin, waters and biota, vol 1. Texas A \& M University Press, USA, pp 751-788

Field JG, Clarke KR, Warwick RM (1982) A practical strategy for analysing multispecies distribution patterns. Mar Ecol Prog Ser $8: 37-52$

Gambi MC, Giangrande A (1985) Caracterizzazione e distribuzione delle categorie trofiche dei policheti nei fondi mobili del Golfo di Salerno. Oebalia 11:223-240

Gaston GR (1987) Benthic polychaeta of the Middle Atlantic Bight: feeding and distribution. Mar Ecol Prog Ser 36:251-262

Granados Barba A (2001) Los poliquetos bénticos de la región petrolera del suroeste del Golfo de México: estructura comunitaria e impacto ambiental. Tesis Doctoral, Universidad Nacional Autónoma de México, México

Granados Barba A, Domínguez Castanedo N, Rojas López R, Solís Weiss V (2009) El Estudio Ecológico de los Anélidos Poliquetos de la Bahía de Campeche. In: De León González JA (ed) Poliquetos (Annelida: Polychaeta) de México y América Tropical. Universidad Autónoma de Nuevo León, Nuevo León

Gray JS (1981) The ecology of marine sediments (an introduction to the structure and function of benthic communities). Cambridge University Press, New York

Heip JS (1992) Benthic studies: summary and conclusions. Mar Ecol Prog Ser 91:265-269

Hentschel BT, Larson AA (2005) Growth rates of interface-feeding polychaetes: combined effects of flow speed and suspended food concentration. Mar Ecol Prog Ser 293:119-129

Hernández Arana HA, Rowden AA, Atrill MJ, Warwick RM, Gold Bouchot G (2003) Large-scale environmental influences on the benthic macroinfauna of the southern Gulf of Mexico. Estuar Coast Shelf Sci 58:825-841

Hernández Arana HA, Warwick RM, Atrill MJ, Rowden AA, Gold Bouchot G (2005) Assessing the impact of oil-related activities on benthic macroinfauna assemblages of the Campeche shelf, southern Gulf of Mexico. Mar Ecol Prog Ser 289:89-107

Lindsay SM, Woodin SA (1995) Tissue loss induces switching of feeding mode in spionid polychaetes. Mar Ecol Prog Ser 125: $159-169$
Manly BF (1990) Randomization and Monte Carlo methods in biology. Chapman and Hall, London

Maurer D, Leathem W (1981) Polychaete feeding guilds from George Bank, USA. Mar Biol 62:161-171

Maurer D, Leathem W, Menzie C (1981) The impact of drilling fluid and well cuttings on Polychaete feeding-guilds from the US Northeastern continental shelf. Mar Pollut Bull 12:342-347

Merino M (1997) Upwelling on the Yucatan Shelf: hydrographic evidence. J Mar Syst 13:101-121

Muniz P, Pires AMS (1999) Trophic structure of polychaetes in the Sâo Sebastiâo channel (southeastern Brazil). Mar Biol 134: 517-528

Pagliosa PR (2005) Another diet of worms: the applicability of polychaete feeding guilds as a useful conceptual framework and biological variable. Mar Ecol 26:246-254

Paiva PC (1993) Trophic structure of a shelf polychaete taxocenosis in southern Brazil. Cah Biol Mar 35:39-55

Pinedo S, Sardá R, Martin D (1997) Comparative study of the trophic structure of soft-bottom assemblages in the bay of Blanes (Western Mediterranean Sea). Bull Mar Sci 60(2):529-542

Salas de León DA, Monreal Gómez MA, Colunga Enríquez G (1992) Hidrografía de la Bahía de Campeche. Geofis Int 31(3):315-323

Snelgrove P, Butman CA (1994) Animal-sediment relationships revisited: cause versus effect. Oceanogr Mar Biol Annu Rev 32:111-177

Snelgrove P, Blackburn TH, Hutchings PA, Alongi DM, Grassle JF, Hummel H, King G, Koike I, Lambshead PJD, Ramsing NB, Solís Weiss V (1997) The importance of marine biodiversity in ecosystem processes. Ambio 26:578-583

ter Braak CJF (1988) A fortran program for canonical community ordination by partial, detrended, canonical, correspondance analysis. Version 2.1 technical report: LWA-88-02. Agricultural Mathematics Group, Wageningen

Uebelacker JM, Johnson PG (1984) Taxonomic Guide to the Polychaetes of the Northern Gulf of Mexico. Final report to the minerals management service, contract 14-12-001-29091. Mobile, Alabama

Wieking G, Kröncke I (2003) Macrofauna communities of the Dogger Bank (central North Sea) in the late 1990s: spatial distribution, species composition and trophic structure. Helgol Mar Res 57:34-46

Yáñez Arancibia A, Day JW (2004) Environmental sub-regions in the Gulf of Mexico coastal zone: the ecosystem approach as an integrated management tool. Ocean Coast Manage 47:727-757

Yáñez Arancibia A, Sánchez Gil P (1983) Environment behavior of Campeche Sound ecological system, off Terminos Lagoon, Mexico; preliminary results. Anales del Instituto de Ciencias del Mar y Limnología UNAM 10(1):117-136 